\title{
Correction to: Interaction of drought and frost in tree ecophysiology: rethinking the timing of risks
}

\author{
Guillaume Charrier ${ }^{1}$ (D) Nicolas Martin-StPaul ${ }^{2} \cdot$ Claire Damesin $^{3} \cdot$ Nicolas Delpierre $^{3} \cdot$ Heikki Hänninen $^{4} \cdot$ \\ Jose M. Torres-Ruiz ${ }^{1} \cdot$ Hendrik Davi $^{2}$
}

Published online: 9 July 2021

(c) The Author(s) 2021

\section{Correction to: Annals of Forest Science https://doi.org/10.1007/s13595-021-01052-5}

The article, Interaction of drought and frost in tree ecophysiology: rethinking the timing of risks, written by G. Charrier, N. Martin-StPaul, and C. Damesin et al., was originally published electronically on the publisher's internet portal on 12 April 2021 without open access. With the author(s)' decision to opt for Open Choice the copyright of the article changed on 10 March 2021 to $\odot$ The Author(s) 2021 and the article is forthwith distributed under a Creative Commons Attribution CC BY 4.0 International License, which permits use, sharing, adaptation, distribution, and reproduction in any medium or format, as long as you give appropriate credit to the original author(s) and the source, provide a link to the Creative Commons licence, and indicate if changes were made. The images or other third party material in this article are included in the article's Creative Commons licence, unless indicated otherwise in a credit line to the material. If the material is not included in the article's Creative Commons licence and your intended use is not permitted by statutory regulation or exceeds the permitted use, you will need to obtain permission directly from the copyright holder. To view a copy of this licence, visit http//creativecommons. org/licenses/by/4.0.

Publisher's note Springer Nature remains neutral with regard to jurisdictional claims in published maps and institutional affiliations.

This paper is part of the Topical Collection on Disturbances under climate change-Impacts of natural disturbances on forest ecosystems under climate change: large-scale analysis and modelling.

The original article can be found online at https://doi.org/10.1007/ s13595-021-01052-5.

Guillaume Charrier guillaume.charrier@inrae.fr

Nicolas Martin-StPaul nicolas.martin@inrae.fr

Claire Damesin claire.damesin@u-psud.fr

Nicolas Delpierre nicolas.delpierre@u-psud.fr

Heikki Hänninen hhannin@zafu.edu.cn

Jose M. Torres-Ruiz Jose.Torres-Ruiz@inrae.fr
Hendrik Davi

hendrik.davi@inrae.fr

1 INRAE, PIAF, Université Clermont Auvergne, 63000 Clermont-Ferrand, France

2 INRAE, URFM, Domaine Saint Paul, INRAE Centre de Recherche PACA, 228 route de l'Aérodrome, CS 40509 Domaine Saint-Paul, Site Agroparc, France

3 Ecologie Systématique Evolution, Univ. Paris-Sud, CNRS, AgroParisTech, Université Paris-Saclay, Orsay, France

4 State Key Laboratory of Subtropical Silviculture, Zhejiang Agriculture \& Forestry University, Hangzhou 311300, China 